\title{
Refleksje nad Witkiewiczowską filozofią matematyki
}

Konsekwencją destrukcyjnych działań drugiej wojny światowej było rozproszenie i zdekompletowanie matematycznych uwag Stanisława Ignacego Witkiewicza zawartych w jego rękopisach. Na podstawie ocalałych fragmentów Witkiewiczowskiej spuścizny usiłuję zrekonstruować programowe tezy jego filozofii matematyki. Wyjaśniam stosunek Witkiewicza - jako konceptualisty - do platońskiego realizmu. Również w perspektywie sporu z platonizmem sytuuję jego poglądy na tle matematycznego strukturalizmu. Porównuję poglądy Witkiewicza z poglądami Wittgensteina, D. Hilberta, G. Hellmana i S. Shapiro. Badam relację Witkiewiczowskiej filozofii do platonistycznej filozofii K. Gödla.

Byłoby to zgodne $\mathrm{z}$ Witkiewiczowskim programem ontologizacji matematyki ${ }^{1}$, gdyby prawdziwość zdań matematyki ujmować nie tylko jako wynikłą z reguł syntaktycznych (choćby z przestrzegania zasady niesprzeczności), lecz także jako konsekwencję uwzględnienia wymiaru semantyczno-ontologicznego. Należy wziąć pod uwagę odniesienie zdań matematyki do matematycznych przedmiotów. Ale do jakiego rodzaju przedmiotów? Czy myślanych

\footnotetext{
${ }^{1}$ Krzysztof Kościuszko, „O Witkiewiczowskim programie ontologizacji matematyki. Cz. 1”, Witkacy! 2 (2017): 66-68. Krzysztof Kościuszko. „O Witkiewiczowskim programie ontologizacji matematyki. Cz. 2", Witkacy! 3 (2017): 102-109.
} 
jako pozaprzestrzenne i pozaczasowe przedmioty platońskiego realizmu, czy też jako konkretne przedmioty fizyczne? Przede wszystkim powinniśmy uwzględniać obszar znaczeń towarzyszących abstrakcyjnym formułom matematyki, ale to nie wystarcza. W ontologii chodziłoby jeszcze o znalezienie związku między znaczeniami a strukturą samej rzeczywistości fizycznej. Bardzo często bowiem zdarza się, że matematycy mają do czynienia z jakimś zbiorem matematycznych przedmiotów, a raczej z ich strukturą, co do której jeszcze nie wiadomo, czy reprezentuje ona coś materialno-fizycznego. Matematycy niezbyt się tym przejmują, jednakże chwilowy brak takiego empirycznego odniesienia nie oznacza, że takie powiązanie z fizyczną empirią w ogóle nie istnieje. Ma to znaczenie dla matematycznego przyrodoznawstwa i dla filozofii. Dla fizyka jest to niezmiernie ważna kwestia praktyczna: czy formalnym strukturom matematyki odpowiadają jakieś ontyczne struktury realno-fizycznego świata - podobnie dla filozofa bardzo istotne jest pytanie o to, czy matematyka w swym rozwoju jest czy nie jest, względnie do jakiego stopnia jest ufundowana w strukturach fizycznej i metafizycznej (względnie ontologiczno-metafizycznej) rzeczywistości. Witkacy na przykład wyprowadzał przestrzeń geometryczną z przestrzeni fizyki teoretycznej, tę ostatnią z przestrzeni fizyki empirycznej (tzw. „przestrzeni rzeczywistej fizyki”). Wyliczone rodzaje fundował jednak dalej w przestrzeniach ontologicznych: w „nieskończonej rzeczywistej przestrzeni całości istnienia” i w „przestrzeniach rzeczywistych istnień poszczególnych"2

Witkacy był umiarkowanym nominalistą (konceptualistą), tzn. uważał, że pojęcia ogólne istnieją jako abstrakcyjne twory i wytwory ludzkiego umysłu; istnieją wraz ze skorelowaną z nimi ogólną przedmiotowością (tym, o czym te pojęcia mówią), którą z kolei można traktować jako indywidualny symbol wielu podobnych do siebie, indywidualno-konkretnych przedmiotów. Jeśli pojęcia matematyczne są wytworami umysłu, to nie powinny być w swej egzystencji od niego niezależne, a jednak Witkacy przyznając im względną zależność (wynika to z założeń jego „poprawionego psychologizmu” wywodzącego pewne, ale tylko pewne prawa logiki matematycznej z praw psychologii), uwzględniał też to, że są one $\mathrm{w}$ jakimś sensie niezależne. W jakim sensie? W tym, że struktura przedmiotowości (wyznaczonej przez pojęcia) przejawia się w myślanych treściach (znaczeniach, sensach), które nie są przecież tym samym, czym są same podmiotowe przeżycia; a poza tym matematyczna

${ }^{2}$ Stanisław Ignacy Witkiewicz, Pojęcia i twierdzenia implikowane przez pojęcie istnienia (Warszawa: Państwowy Instytut Wydawniczy, 2011), 53-55. 
przedmiotowość współkształtuje się w konfrontacji z zewnętrzną (niezależną od podmiotu) przedmiotowością fizyczną. Te myślane treści (sensy) matematyczne - choć różnią się od skorelowanych z nimi podmiotowych aktów psychicznych - nie egzystują jednak w transcendentnym świecie platońskich idei, istnieją raczej w intersubiektywnym świecie ludzkiej kultury. Jako uczestnicy matematycznej kultury sięgamy po matematyczne wzory, aby ewentualnie opanować zjawiska empirycznego świata. Co to są wzory? Są to znaki wyrażające pewne matematyczne sensy (treści), którym z kolei odpowiadają matematyczne przedmioty, a tym ostatnim mogą odpowiadać przedmioty fizyczne (dlatego matematyką interesują się empirycznie nastawieni przyrodnicy). Na świat matematycznej kultury składają się między innymi matematyczne pojęcia, czyli intersubiektywnie akceptowalne znaki obciążone intersubiektywnie akceptowanymi matematycznymi treściami; jeśli zaś ani myślane treści (sensy), ani związane z nimi przedmioty nie odsyłają nas do transcendentno-platońskiego świata, to oznacza to, że te treści (znaczenia i sensy) istnieją tylko w świecie pojęć jako doczepione do znaków informacje. Informacje kształtują się w matematycznej praktyce językowej, w zjawisku matematycznej komunikacji. Logika z matematyką są zakorzenione zarówno $\mathrm{w}$ ontologii, w psychologii jak i w praktykach lingwistycznych, np. w konwencjonalistycznych praktykach definiowania znaków ${ }^{3}$. Znaki można definiować tak jak to robił D. Hilbert ${ }^{4}$, który jako strukturalista określał matematyczne znaki i pojęcia pierwotne poprzez układ aksjomatów. W perspektywie Hilberta liczby nie dają się pojąć poza formalną strukturą, w ramach której funkcjonują. To samo dotyczy tworów geometrycznych definiowanych aksjomatycznie. W „Podstawach geometrii” Hilbert posługiwał się uwikłanymi definicjami geometrycznych pojęć, tj. dane pojęcie było charakteryzowane przez sieć relacji, w ramach których to pojęcie uzyskiwało znaczenie. Nie zakłada się tutaj, że dane pojęcie miałoby mieć jakieś pierwotne (absolutne) znaczenie uobecniające się np. w intuicji i że dane aksjomaty miałyby biernie je wyrazić. W strukturze systemu konstytuującego znaczenia abstrahuje się od wszelkich cech danego przedmiotu, które nie byłyby wyznaczone przez system relacji ${ }^{5}$. Jednakże mamy tu problem: czy obiekty matematyczne są w całości tożsame $\mathrm{z}$ rolą, jaką wyznaczają im aksjomaty i dany system ma-

\footnotetext{
${ }^{3}$ Stanisław Ignacy Witkiewicz, Zagadnienie psychofizyczne, oprac. Bohdan Michalski (Warszawa: PWN, 1978), 214-215.

${ }^{4}$ Witkiewicz, Pojęcia i twierdzenia implikowane przez pojęcie istnienia, 198.

${ }^{5}$ Paul Bernays, Hilbert, David, w: Paul Edwards, ed. The Encyclopedia of Philosophy, vol. 3. 496-504 (New York: Macmillan and The Free Press, 1967), 495-504.
} 
tematyczny (jak w geometrii Hilberta), czy też przysługuje im jakaś autonomia, jakiś sens niezależny od całościowego kontekstu aksjomatyczno-systemowego? Jeśli będziemy ujmować obiekty jako zupełnie niezależne od całościowych kontekstów aksjomatyczno-systemowych, to może nam grozić popadnięcie $\mathrm{w}$ realizm platoński, ale niekoniecznie. Witkacy $\mathrm{w}$ taki realizm nie popadł. Rozpatrzmy dla przykładu sens pojęcia „linii prostej”. Ten sens zmienia się zależnie od kontekstu aksjomatycznego danej geometrii (euklidesowej albo nieeuklidesowej), ale $\mathrm{z}$ drugiej strony linia prosta rozpatrywana w kontekście naszej codziennej czasoprzestrzeni przestaje być zależna od takiej czy innej aksjomatyki, a staje się tożsama np. z obserwowanymi liniami torów przemieszczania się albo spoczywania danych obiektów fizycznych. Gdy będziemy obserwować „utwory proste statyczne”, np. linię horyzontu albo linię rozchodzenia się światła ${ }^{6}$, dojdziemy do pojęcia prostej płaskiej euklidesowej, do pojęcia teoriopoznawczo "pierwotnego", nie uzależnionego od kontekstów różnych nieeuklidesowych systemów aksjomatycznych. To pojęcie "prostej euklidesowej” jest pojęciem teoriopoznawczo i ontologicznie pierwotnym w stosunku do pojęć "prostych nieeuklidesowych", ale jest też pojęciem pierwotnym w stosunku do aksjomatyki Euklidesa, bo zdaniem Witkacego to właśnie ta aksjomatyka jest dostosowana do pojęcia zaczerpniętego z naszych codziennych intuicji, intuicji zmysłowych, a nie transcendentno-platońskich.

Gdybyśmy chcieli zaklasyfikować powyższe stanowisko Witkacego, powiedzielibyśmy, że jest on nie-redukcyjnym strukturalistą, tzn. że według niego przedmioty matematyczne są tylko częściowo określalne przez całość danego systemu matematycznego; że mimo tego podporządkowania się całości relacji (jak u Hilberta) posiadają one jednak pewne cechy nieredukowalne do cech wyznaczonych przez strukturę całości. Te cechy prezentują się nam w intuicjach matematycznych odkrywających to, co bezpośrednio dane, odsłaniają elementy niejako czekające na zdefiniowanie (chodzi o zdefiniowanie na podstawie intuicji, a nie o definicje dokonywane z perspektywy systemowej całości), zaksjomatyzowanie i wchłonięcie w procedury dedukcyjne. Cechy prezentujące się w intuicjach mogą być cechami zarówno przedmiotów abstrakcyjnych (nominalistycznie interpretowanych), jak i przedmiotów fizycznych.

\footnotetext{
${ }^{6}$ Witkiewicz, Zagadnienie psychofizyczne, 247.

${ }^{7}$ Ibidem, 248.
} 
Według Witkacego matematyka jest i nie jest zakorzeniona w materialnym świecie. Systemy matematyczne są określalne przez struktury materialnej przedmiotowości, ale są też określalne przez przedmiotowość abstrakcyjną (idealną): po prostu jedne abstrakcyjne struktury wynikają z drugich, ale ta abstrakcyjność nie jest rozumiana po platońsku. Te abstrakcje same w sobie są symbolami wielości indywidualnych przedmiotów matematycznych, które ostatecznie mogą zostać powiązane $\mathrm{z}$ konkretną przedmiotowością materialną; więc jeśli autor „Zagadnienia psychofizycznego” był empirykiem i nominalistą, to nie do końca w stylu H. Fielda, który negował wszelki wymiar abstrakcyjno-idealny ${ }^{8}$. Według Fielda obiekty abstrakcyjne w ogóle nie istnieją, a twierdzenia matematyczne niczego nam nie mówią o poza-matematycznej rzeczywistości. Witkacy proponował program nominalistyczno-konceptualistycznej ontologizacji matematyki.

Czy Witkacy miał coś wspólnego z Wittgensteinem? Z autorem „Uwag o podstawach matematyki" łączyły go: antyplatonizm oraz pewne elementy intuicjonizmu matematycznego ${ }^{9}$. Zgodne $\mathrm{z}$ poglądami Wittgensteina było akcentowanie tego, że sensu matematycznej przedmiotowości nie da się zredukować do sensu narzuconego przez wymogi aksjomatyczno-systemowe jest to szczególnie widoczne w Witkiewiczowskiej krytyce filozoficznych założeń związanych z geometriami nieeuklidesowymi. Z jednej strony Witkacy zdawał sobie sprawę, że bez spekulacji kreujących zupełnie nie-intuicyjne sensy (i używających uwikłanych definicji pojęć) nie byłoby postępu w matematyce, ale $\mathrm{z}$ drugiej strony w sporze ze zwolennikami geometrii nieeuklidesowych bronił intuicyjnego sensu pewnych pojęć przeciw nadmiernym uproszczeniom analityczno-formalnego myślenia spekulatywnego (taka podejście zbliżało go do postawy Hermana Weyla $\left.{ }^{10}\right)$.

Czy Witkiewiczowska filozofia matematyki ma coś wspólnego ze współczesnym strukturalizmem? Ponieważ Witkacy był nominalistą - więc może istnieje jakieś pokrewieństwo z nominalistycznym strukturalizmem G. Hellmana? Przecież także Hellman odnosił się krytycznie do platonizmu (w tym:

${ }^{8}$ Hartry Field, Realism, Mathematics and Modality (Oxford: Basil Blackwell, 1989), 1-53.

${ }^{9}$ Swój stosunek do Wittgensteina z okresu Traktatu logiczno-filozoficznego Witkiewicz bardzo szczegółowo wyraził w „Krytyce poglądów Ludwika Wittgensteina”. Por.: Stanisław Ignacy Witkiewicz, Pisma filozoficzne i estetyczne (Warszawa: PWN, 1978), 168-237.

${ }^{10}$ Paolo Mancosu, From Brouwer to Hilbert (New York: Oxford University Press, 1998), 65-142. 
do platonizmu strukturalistycznego $)^{11}$. Matematyka według niego nie jest wiedzą o platońsko myślanych obiektach, nie jest też wiedzą o platońskich strukturach. Matematyka zajmuje się strukturami logicznie możliwymi. Jeśli dana struktura matematyczna jest bardzo abstrakcyjna, to nie znaczy, że obcujemy z platońską pozaprzestrzenną istnością, lecz jedynie z logicznie możliwą strukturą teoretyczną, co do której nie powinniśmy pochopnie przyjmować żadnych zobowiązań ontologiczno-metafizycznych. Kiedy istnienie danej struktury jest możliwe? Co decyduje o możliwości istnienia danej struktury? Jeśli przyjąć interpretację Wójtowicza ${ }^{12}$, to możliwe istnienie danej matematycznej struktury według Hellmana jest uzależnione od struktury teorii empirycznej, w której ją się stosuje. Podobnie tę sprawę ujmuje Witkacy, bo także u niego jest obecny ten Hellmanowski motyw ujmowania matematyki jako nauki o możliwych strukturach; także u niego chodzi o możliwość istnienia tych struktur, a o tym możliwym istnieniu miałyby decydować empiryczne zastosowania. Kiedy np. Witkacy rozpatruje stosunek geometrii euklidesowej do geometrii nieeuklidesowych ${ }^{13}$, pokazuje, że struktura geometrii euklidesowej może przejść w strukturę geometrii nieeuklidesowej przy spełnieniu pewnych warunków (nie tylko logicznych), a mianowicie wtedy, gdy uwzględnimy wpływ pól grawitacyjnych i elektromagnetycznych na zakrzywienie przestrzeni; a więc dla Witkacego dyskurs o możliwych strukturach geometrycznych był fragmentem szerszego dyskursu dotyczącego funkcjonowania matematyki w naukach empirycznych.

Za to niewiele wspólnego ma Witkiewiczowska filozofia matematyki ze strukturalizmem ante rem S. Shapiro - tym bardziej, że Shapiro był platonikiem. Shapiro jako platoński strukturalista jest przekonany o realnym istnieniu struktur matematycznych, które nie są czasoprzestrzennie lokalizowalne ${ }^{14}$. Jeśli według Witkacego ten sam powszechnik matematyczny (oczywiście nominalistycznie zinterpretowany) może się uobecniać w różnych miejscach przestrzeni, to ma to oczywiście materialne przyczyny, natomiast Shapiro ma problem z wyjaśnieniem sposobu uobecniania się nieprzestrzennych i pozaczasowych przedmiotów matematycznych w czasoprzestrzennych umysłach ludzi zajmujących się matematyką. Poza tym z perspektywy Witkacego liczby

${ }^{11}$ Geoffrey Hellman, Modal-Structural Mathematics, w: A. D. Irvine. ed., Physicalism in Mathematics (Dordrecht: Kluver, 1990), 307-330.

${ }^{12}$ Krzysztof Wójtowicz, Spór o istnienie w matematyce (Warszawa: Semper, 2003), 229.

${ }^{13}$ Witkiewicz, Zagadnienie psychofizyczne, 246-251.

${ }^{14}$ Stewart Shapiro, Philosophy of Mathematics. Structure and Ontology (Oxford University Press, 1997), 72-74. 
nie są jedynie „office places” w strukturze liczb naturalnych. Tak samo linie proste nie są tylko i wyłącznie pewnymi rolami w strukturze geometrii euklidesowej. Według Witkacego przedmioty matematyczne (np. linie proste) mogą być określone przez miejsce zajmowane w strukturze, ale są też określalne przez intuicyjny (zmysłowy albo intelektualny) kontakt z tworami zwanymi „liniami prostymi”.

Witkacy proponował swego rodzaju syntezę logicyzmu-formalizmu (zwanych przez niego „poglądem logicznym”) z intuicjonizmem ${ }^{15}$. Czy taka synteza jest realizowalna? Rozważmy tę możliwość. Z jednej strony wiadomo, że nie da się oprzeć całej matematyki na konstrukcjach logiczno-formalnych; dowiodło tego (o czym Witkacy nie wiedział) twierdzenie Gödla. Trzeba by uwzględnić intuicję, ale „intuicję” jak rozumianą? Czy w stylu Brouwera? Przecież według Brouwera zarówno matematyczna praintuicja (tzw. „dwójjednia”), jak i oparte na niej konstrukcje są niezależne od zewnętrznej rzeczywistości: są one uwolnionymi od zewnętrznych nacisków wewnętrznymi erupcjami tego, co dane w introspekcji. W przeciwieństwie do poglądu Witkacego czynniki ontyczne nie odgrywają tutaj żadnej roli w genezie matematyki. Metody konstruowania twierdzeń nie są zaczerpnięte $\mathrm{z}$ obserwacji matematycznej przedmiotowości. Niewiele wspólnego ma to z ontologizującym podejściem Witkacego. Jednakże również Brouwerowskie lekceważenie matematycznego języka ${ }^{16}$ nie pasuje do programu Witkacego, według którego matematyka może się konstytuować nie tylko w zetknięciu z zewnętrzną rzeczywistością, ale także $\mathrm{w}$ kontakcie $\mathrm{z}$ innymi jaźniami posługującymi się symbolami językowo-matematycznymi. U Brouwera uderza zbyt duży nacisk położony na wątki solipsystyczne. A przecież u źródeł wielu teorii matematycznych leży dialog między przedstawicielami przeciwstawnych poglądów, dialog, spór i ewentualnie consensus. Propagowaniem dialogiczności zajmie się później Imre Lakatos ${ }^{17}$. Jeśli więc istnieje jakakolwiek zbieżność wątków szeroko pojętego intuicjonizmu $\mathrm{z}$ tendencjami Witkiewiczowskiej filozo-

\footnotetext{
${ }^{15}$ Stanisław Ignacy Witkiewicz, Nauki ścisłe a filozofia, oprac. Maciej Dombrowski, Magdalena Bizior-Dombrowska (Warszawa: Państwowy Instytut Wydawniczy, 2014), 166-168.

${ }^{16}$ Luitzen Egbertus Jan Brouwer, Mathematics, Science and Language, w: Paolo Mancosu, From Brouwer to Hilbert (New York: Oxford University Press, 1998), 45-53.

${ }^{17}$ Davies Philip J., Reuben Hersh, Świat matematyki, tłum. Roman Duda (Warszawa: PWN, 1994), 302-314.
} 
fii matematyki, to na pewno nie będzie to tożsamość rozumienia „intuicji” u Witkacego i Brouwera. Raczej „intuicja” H. Poincarégo może też jakieś elementy husserlowskiego rozumienia „intuicji” byłyby tu bardziej na miejscu. „Intuicja” u Witkacego polega między innymi na bezpośrednim oglądaniu danej (idealnej albo realnej) przedmiotowości, nie jest ona jednak jak u Brouwera - materiałem, z którego konstruuje się tę przedmiotowość. U Brouwera konstrukcja matematyczna jest następstwem wewnętrznych aktów, ale treścią tych aktów nie jest zewnętrzna przedmiotowość. Dlaczego więc Witkacy akceptował intuicjonizm? Znany jest przychylny stosunek Witkacego do intuicjonizmu H. Poincarego ${ }^{18}$, ale akceptując idee autora „Nauki i hipotezy” utożsamiał się z wątkami, które później rozwijali inni intuicjoniści, w tym Brouwer. Chodzi mianowicie o to, że intuicjoniści bardzo krytycznie ustosunkowywali się do teoriomnogościowo-logicznych prób opisania zbiorów aktualnie nieskończonych, do próby zastosowania finitystycznej matematyki i klasycznej logiki do nieskończoności zaktualizowanej. Przecież bowiem na przykład prawo wyłączonego środka znajduje zastosowanie tylko $\mathrm{w}$ odniesieniu do zbiorów skończonych. Podobnie jest $\mathrm{z}$ matematycznymi dowodami nie wprost, tj. dowodami afirmującymi jakąś tezę poprzez wykazanie absurdalności tezy przeciwnej - czyż nie są one oparte na prawie wyłączonego środka? A więc czyż ich użyteczność nie jest ograniczona do obszarów matematycznej skończoności? Dlaczego więc logicyści stosują je do zaktualizowanej nieskończoności?

Ostrze intuicjonistycznej krytyki zwróciło się także przeciw użyciu nie-predykatywnych definicji; albowiem jak można np. definiować liczbę rzeczywistą przez odwołanie się do całego zbioru liczb rzeczywistych? Tego typu definiowanie jest przykładem ulegania niewłaściwej procedurze tzw. „błędnego koła”. Nic dziwnego, że według intuicjonistów teoriomnogościowe próby ufundowania matematyki wiodą do antynomii i paradoksów. Aby ich uniknąć, Poincaré doradzał ograniczenie się do zbiorów przeliczalnych i unikanie niepredykatywności ${ }^{19}$, i z tą jego radą Witkacy zgadzał się całkowicie. Ewentualnie trzeba sprowadzać zdania o aktualnej nieskończoności do zdań o nieskończoności potencjalnej. Jednakże pozostawanie w obszarze zbiorów przeliczalnych jest przejawem podporządkowania tego, co abstrakcyjne działaniu intuicji, podporządkowaniem gwarantującym uniknięcie antynomii dlatego Witkacy w tym punkcie akceptował intuicjonizm. $\mathrm{Z}$ drugiej jednak

\footnotetext{
${ }^{18}$ Witkiewicz, Nauki ścisłe a filozofia, 180-181.

${ }^{19}$ Ibidem.
} 
strony, czy trzymanie się rozwiązań intuicyjnych może być panaceum na wszystkie bolączki matematyków? Przecież bardzo często - jak na to wskazują formaliści - matematycy poruszają się w abstrakcjach nie mających na pierwszy rzut oka - nic wspólnego z jakimikolwiek intuicjami, a jednak są to abstrakcje niezbędne. Punktem wyjścia takich abstrakcji mogą być definicje aksjomatyczne takie, w których znaczenia terminów pierwotnych nie są określane przez odwołanie się do intuicji (zmysłowych albo niezmysłowych), lecz przez podanie układu aksjomatów mogących konstytuować dowolne znaczenia nieintuicyjne. Stosując takie definicje przez postulaty w kontekście ogólno-abstrakcyjnych rachunków (a więc rachunków zupełnie nieintuicyjnych), matematycy mogą wyrażać się w sposób bardzo ścisły o przedmiotowości znacznie wykraczającej poza to, co w danej chwili uznane jest za intuicyjnie oczywiste. I jeśli uda się im w końcu skorelować chwilowo nieintuicyjne struktury matematyczne $\mathrm{z}$ jakimiś intuicjami, to wszystko $\mathrm{w}$ porządku: synteza formalizmu $\mathrm{z}$ intuicjonizmem byłaby możliwa. Byłaby możliwa, gdyby formaliści spod znaku Hilberta w ogóle jej szukali (udało się to $\mathrm{H}$. Weylowi ${ }^{20}$ ). Problem polega na tym, że w formalistycznej optyce Hilberta matematyczne symbole nie mają znaczeń; że są beztreściowe. Sformalizowana matematyka byłaby o niczym, a jej poznawanie sprowadzałoby się do zaznajomienia się z regułami używania matematycznych znaków. Również te reguły nie miałyby wynikać z obserwacji jakichś treści poza-znakowych. Jeśli jednak matematyka byłaby pozbawiona elementu semantyczno-intuicyjnego, to jakim cudem odsemantyzowana matematyka pasuje do ontycznej struktury czy to świata realnego, czy idealnego? Czy można się zgodzić, że wymiar semantyczno-ontologiczny jest całkowicie obcy matematyce? Czy istota matematyki polega na przestrzeganiu reguł przekształcania jednych znaków w inne? Czy jest ona czystą grą, maszynerią transformowania pustych formuł $\mathrm{w}$ siebie? Jeśli z założenia matematyka nie miałaby mieć żadnych ontycznych odniesień, to dlaczego takie odniesienia pojawiają się w codziennej praktyce matematyków i fizyków? Dlaczego sami teoretycy formalizmu są niekonsekwentni w swym negowaniu warstwy pozasyntaktycznych odniesień? Odpowiadając na te pytania Witkacy zaproponował uzupełnienie syntaktycznej interpretacji Russella-Hilberta elementami podejścia semantyczno-ontologicznego. Na stronie 215 „Zagadnienia psychofizycznego” wyraża przekonanie, że „wychodząc z logistycznych definicji pojęć matematycznych,

${ }^{20}$ Mancosu, From Brouwer to Hilbert, 80-81. 
nie można by stworzyć tej ostatniej (tj. matematyki - uzupełnienie moje)"21, a na stronie 216 powiada, że „formalne, bezznaczeniowe, czysto znaczkowe struktury dopiero na tle znaczeniowych struktur jako abstrakcje powstają"22. Inaczej mówiąc: nie ma logistyczno-formalistycznej syntaksy bez semantyki. Zarówno przedstawiciele logicyzmu, jak i formalizmu łudzą się, sądząc, że czysto formalne rachunki da się odizolować od semantyczno-ontologicznych treści.

Według Witkacego prawdziwość geometrii euklidesowej miałaby wynikać z jej zgodności z postrzeganymi faktami ontycznymi. Niektóre aksjomaty tej geometrii są prawdziwe, bo są oparte na zmysłowej intuicji, na tym, co się w niej prezentuje. Jeśli są prawdziwe, to powinny też być spójne. Natomiast Hilbert stawiał sprawę na odwrót: prawdziwe jest to, co jest spójne, np. aksjomaty są prawdziwe, bo nie przeczą sobie i są zgodne ze swymi konsekwencjami, a ich spójność miałaby gwarantować istnienie tych bytów, o których się $\mathrm{w}$ aksjomatach mówi ${ }^{23}$. W ten sposób ontologia byłaby podporządkowana matematyce i logice. O ile więc Witkacy chciał ontologizować logikę i matematykę, o tyle u Hilberta mamy zmatematyzowaną ontologię: istniałoby to, co jest dozwolone w ramach niesprzecznej struktury matematycznej. W konsekwencji mielibyśmy wielość rzeczywistości, bo każdej matematycznej teorii odpowiadałyby jakieś byty, tak jak każdej możliwej geometrii nieeuklidesowej odpowiadałyby inne przestrzenie, inne geometryczne światy. Która przestrzeń jest „prawdziwa”, tj. która $z$ nich możliwie wiernie opisuje przestrzeń fizycznego świata? Czy należałoby zrezygnować z przestrzeni euklidesowej? A może dałoby się pogodzić wielość możliwych przestrzeni nieeuklidesowych z jedną przestrzenią euklidesowo-newtonowską? Jak wiadomo Witkacy obstawał przy tym, że geometrie nieeuklidesowe mogą być "prawdziwymi” obrazami jakichś wycinków jednej absolutnej przestrzeni ${ }^{24}$. Czy Witkacy akceptował klasyczną definicję prawdy? Jak odnosił się do kryterium niesprzeczności? Z lektury jego pism da się wydedukować następu-

\footnotetext{
${ }^{21}$ Witkiewicz, Zagadnienie psychofizyczne, 215.

${ }^{22}$ Ibidem, 216.

${ }^{23}$ Bedürftig Thomas, Roman Murawski, Philosophie der Mathematik (Berlin: De Gruyter, 2012), 107.

${ }^{24}$ Krzysztof Kościuszko, „Witkacy uwikłany w spór między absolutną a relacyjną teorią przestrzeni", Rocznik Podhalański 11 (2016): 321-336.
} 
jące stanowisko: jeśli jakaś teoria jest prawdziwa, bo zgodna (przynajmniej do pewnego stopnia) z rzeczywistością (czy też z intuicją), to powinna też być niesprzeczna (ewentualnie powinno się o tę niesprzeczność walczyć). Jeśli zaś jakaś nowa, niezweryfikowana jeszcze, teoria jest niesprzeczna, to dlaczego nie mielibyśmy podejrzewać, że odpowiadają jej jakieś nowe, nieuwzględnione dotychczas fakty, tzn. np. jeśli geometrie nieeuklidesowe są niesprzeczne, to dlaczego nie mielibyśmy przyjąć, że rzeczywista przestrzeń może być w jakichś swych fragmentach nieeuklidesowa?

Czyżby obstając przy tezie, że logika i matematyka są zakorzenione w ontologii i że wszystko, co aprioryczne, formalne i abstrakcyjne w tych naukach odzwierciedla konieczną strukturę samego bytu, Witkacy przyjmował jednocześnie istnienie jednej, ustalonej raz na zawsze niezmiennej struktury tegoż bytu i to do tego stopnia, że żaden nowy fakt odkryty przez naukę nie byłby w stanie naruszyć obrazu tej niezmienności? Skąd mamy wiedzieć, że odkryte przez nas związki ontyczne są ostateczną prawdą o bycie? Przecież nauka bez przerwy podważa ustalone prawdy o materii, a tworzone przez naukowców naukowe ontologie nie tylko eliminują ontologie stricte filozoficzne, ale także same siebie. Która ontologia jest prawdziwa? Która będzie prawdziwa? Otóż Witkacy nie negował rozwoju nauki, a opowiadając się np. po stronie geometrii euklidesowej (kontra geometrie nieeuklidesowe) nie był zaślepionym, dogmatycznym konserwatystą. Jego problemem nie było ślepe obstawanie przy przestarzałej geometrii (wszak jej aktualności dowiodła kosmologia neonewtonowska), ale jej uzgodnienie $\mathrm{z}$ nowymi geometriami nieeuklidesowymi. Zarazem chodziło mu o zarysowanie takiej ontologii, w ramach której byłoby miejsce zarówno dla przestrzeni newtonowsko-euklidesowej, jak i przestrzeni einsteinowsko-nieeuklidesowej ${ }^{25}$. Wychodził z założenia, że wszelkie odkryte w przeszłości i odkrywane w teraźniejszości naukowe ontologie są ontologiami szczegółowymi, dotyczącymi jakichś wycinków całego bytu. A więc w ontologii filozoficznej powinny się znaleźć takie konieczne struktury ontyczne, które dałoby się uzgodnić z możliwymi ontologiami naukowymi, przeszłymi i przyszłymi. Chodzi o rozmaite naukowe ontologie, np. ontologie zakładane przez fizykę i ontologie zakładane przez biologię. $Z$ próby uzgodnienia tych dwóch rodzajów ontologii rodzą się rozmaite możliwe stanowiska, które można następnie próbować uzgodnić z takimi filozoficznymi kierunkami jak witalizm, neowitalizm, monadologia, hylozoizm itd. Ale chodzi też o uzgodnienie między sobą możliwych pod-ontologii

${ }^{25}$ Ibidem. 
funkcjonujących w ramach jednej, szerszej dziedziny wiedzy. Na przykład w matematyce sobie współczesnej Witkacy obserwował spór nominalizmu S. Leśniewskiego z realistyczno-platońskimi ontologiami kontynuatorów G. Cantora, preferując wyraźnie stanowisko twórcy mereologii ${ }^{26}$. Odnosząc rozważania Witkacego do współczesnej matematyki, powiedzielibyśmy, że np. obok nominalistycznej ontologii G. Hellmana mamy opozycyjną, strukturalistyczno-platońską ontologię S. Shapiro - czy któraś z nich ma większe szanse na rozwiązanie problemów nękających współczesną matematykę i filozofię matematyki? A może platonizm K. Gödla byłby właściwszym stanowiskiem? Zresztą w myśleniu jednego matematyka czasem funkcjonują dwie ontologie, np. w przypadku K. Gödla nie wiadomo, jak pogodzić jego platoński realizm z tezą, według której o akceptowalności nowych matematycznych aksjomatów miałaby decydować ich płodność w fizyce.

Jeśliby szukać myśliciela o poglądach z lekka podobnych do poglądów Witkacego, to byłby nim np. Kurt Gödel. Dlaczego? Choćby dlatego, że 1) ambicją filozoficzną Gödla było stworzenie systemu metafizycznego będącego jakąś odmianą monadologii ${ }^{27}$, 2) obaj krytycznie odnieśli się do antymetafizycznego programu neopozytywistów, 3) według nich nauki szczegółowe mają charakter hipotetyczny, nie są one w stanie zastąpić całościowo-istotnościowych badań metafizycznych, 4) obaj odrzucali pogląd, że matematyka ma tylko i wyłącznie składniowy charakter. Różnica między nimi (nie jest to jedyna różnica) polega na tym, że Witkacy stworzył syntezę biologicznego materializmu z „poprawionym psychologizmem”, podczas gdy Kurt Gödel obstawał przy spirytualizmie. Jeśliby Gödel stworzył swoją wymarzoną metafizykę, byłaby to zapewne jakaś spirytualistyczna monadologia, a nie monadologia biologiczna. Poza tym Gödel uważał się za platonika (czy słusznie?); uznawał, że przedmioty matematyczne istnieją niezależnie od nas, od aktów podmiotowości, istnieją też niezależnie od przedmiotów fizycznych. Natomiast według Witkacego przedmiotowość matematyczna jest i nie jest zależna od przeżyć mentalnych; jest też i nie jest zależna od przedmiotowości fizycznej (nie ma tu sprzeczności). Witkacy - w przeciwieństwie do Gödla -

\footnotetext{
${ }^{26}$ Witkiewicz, Nauki ścisłe a filozofia, 182.

${ }^{27}$ Hao Wang, Logical Journey: From Gödel to Philosophy (Cambridge: The MIT Press, 1997), 166.
} 
nie odrzucał psychologizmu, ale przyznawał też rację antypsychologistom (według których prawa logiki wyrażają obiektywne stany rzeczy) ${ }^{28}$. Twórca biologicznej monadologii akceptował też fakt, że twierdzenia matematyczne są prawdziwe na mocy znaczeń pojęć (a nie na mocy ich syntaktycznej struktury), ale nie łączył tego - jak Gödel - z platońsko-realistycznym rozumieniem obiektów matematycznych. Według Witkacego trzeba odróżnić znaczenia konkretne (odnoszące się do indywidualnych przedmiotów czasoprzestrzennych) od abstrakcyjnych i te ostatnie (odnoszące się do przedmiotowości pozafizycznej) sprowadzić do tych pierwszych. Zresztą Gödel w późniejszej fazie swej twórczości doszedł do wniosku, że np. o wyborze aksjomatów matematycznych (które są zdaniami prawdziwymi) miałaby decydować ich płodność w obszarze fizyki ${ }^{29}$. A więc może jednak matematyczne zdania mówią coś (w sposób bardzo pośredni) o świecie fizycznym?

Gödel jako „platonik” akceptował niepredykatywne metody teorii mnogości - różniło go to od Witkacego, który jako zwolennik konstruktywizmu Poincarégo widział w tych metodach działanie błędnego koła. Według Witkacego nie powinno się zakładać, że aktualnie nieskończone zbiory liczb istnieją jako coś „danego”, „gotowego”. Dyskurs o aktualnej nieskończoności powinno się sprowadzić do dyskursu o nieskończoności potencjalnej. Wszystkie twierdzenia teorii mnogości powinno się „konstruować”.

Obu filozofów łączyło wspólne krytyczne podejście do wyznawanej przez neopozytywistów, antymetafizycznej interpretacji matematyki. Obaj krytykowali Carnapa, według którego pojęcia matematyczne nie desygnują żadnych bytów: ani konkretnych, ani abstrakcyjnych, sama zaś matematyka miałaby być dedukcyjną grą na znakach używanych zgodnie ze składniowymi konwencjami. Jednak wspólne negatywne podejście do Carnapa podyktowane było różnymi ontologiami: platonizującą Gödla i nominalistyczną Witkacego. Jeśli według Carnapa matematyka wyrażała składniowe konwencje ustalające sposób użycia matematycznych znaków, to Witkacy proponował zontologizowanie konwencjonalizmu. Dlaczego? Bo jeśli syntaktyczne konwencje (dotyczące użycia znaków) służą jedynie syntaktycznym celom, to stają się - podobnie jak i one - beztreściowym elementem czysto formalnej gry, a czysto formalna gra (bez semantyczno-ontologicznych odniesień) czyni z matematyki opowieść o niczym. Podobnie Gödel sądził, że nie da

\footnotetext{
${ }^{28}$ Witkiewicz, Zagadnienie psychofizyczne, 211-212.

${ }^{29}$ Stewart Shapiro, Thinking about Mathematics (Oxford University Press, 2000), 211.
} 
się zastąpić matematycznych intuicji przez konwencje ${ }^{30}$. Rozpatrywanie syntaksy łącznie z semantyką jest punktem wspólnym łączącym Witkacego z Gödlem, według którego sformalizowana matematyka jest czymś wtórnym $\mathrm{w}$ stosunku do rozumienia znaczenia pojęć. Semantyczno-ontologiczne podejście Witkacego do konwencjonalizmu wyraża się w tym, że według niego uprawianie syntaktycznej gry bez semantyki i ontologii staje się zajęciem bez znaczenia i bez sensu (jest to stwierdzenie odwrotne do stwierdzeń Carnapa, który chciał wykazać bezsensowność wszelkiej ontologii przekraczającej reguły składni). Po co wprowadzać syntaktyczne konwencje do syntaktycznej gry, jeśli ta gra jest bez jakiejkolwiek treści poznawczej? Równie bezsensowne jest rozpatrywanie samej warstwy znaczeniowej bez jej odniesienia do jakichś ontycznych faktów (idealnych albo realnych).

„Platonizm” Gödla nie jest co prawda tożsamy z mityczno-transcendentnym platonizmem samego Platona (jest raczej koncypowany w duchu Husserla), a w umiarkowanym nominalizmie czy też konceptualizmie Witkacego abstrakcyjna przedmiotowość matematyczna - obok swego uzależnienia od przeżyć mentalnych matematyków - jest co prawda pojęta jako do pewnego stopnia od tych przeżyć niezależna, ale czy ten fakt mógłby stanowić jakiś pomost łączący platonizm Gödla z nominalizmem Witkacego? Częściowa niezależność matematycznej przedmiotowości od podmiotów polegałaby (w przypadku Witkacego) na tym, że 1) struktura tej przedmiotowości jest w dużej mierze ustalana ze względu na empiryczne fakty, 2) ta przedmiotowość jest składnikiem obiektywnego świata kultury, a przedmioty i wartości świata kultury są przecież częściowo autonomiczne w stosunku do przeżyć mentalnych podmiotów w kulturze uczestniczących - ale Gödel akcentował całkowitą niezależność obiektów matematycznych. Albo weźmy następujący problem: dlaczego różni matematycy mają podobne intuicje? Skąd płynie tożsamość $\mathrm{w}$ rozumowaniach matematyków? Z perspektywy Witkacego ta tożsamość może wynikać z tożsamości matematycznej przedmiotowości stanowiącej część wspólnego świata kultury, ale może też wynikać z podobieństwa biologiczno-psychologicznych struktur rozumujących podmiotów. Tę komponentę filozofii Witkacego rozwinie później znaturalizowana epistemologia reprezentowana między innymi przez Quine'a ${ }^{31}$. Witkacy starał się uwzględnić oba czynniki wpływające na podobne intuicje matematyków,

\footnotetext{
${ }^{30}$ Kurt Gödel, Is Mathematics Syntax of Language? w: Kurt Gödel, Collected Works, vol. III. (Oxford: Oxford University Press, 1995), 358.

${ }^{31}$ Willard Van Orman Quine, Theories and Things (Harvard University Press, 1981), 1-24.
} 
tzn. czynnik przedmiotowej tożsamości i tożsamość biologiczno-psychicznej struktury podmiotów uwikłanych w matematykę.

\section{Podsumowanie}

Zadziwia wszechstronność filozoficzna Witkacego - to, że będąc w analizującym dialogu $\mathrm{z}$ wieloma bardzo wyspecjalizowanym i różnorakimi szkołami myślenia filozoficzno-logiczno-matematycznego, nie zatracił poczucia związku z fundamentalnymi pytaniami filozofii. Być może taki właśnie powinien być filozof: obok perspektywy analitycznej winien posiadać perspektywę całościową. To, że Witkacy nie mógł zaakceptować np. filozofii neopozytywistycznej czy filozofii filozofów szkoły lwowsko-warszawskiej wynikało między innymi z tego, że poszczególne środowiska filozoficzne zbyt się wyspecjalizowały w wąskich kierunkach badań; że zaczęto lekceważyć np. powiązanie filozofii matematyki z szerzej rozumianą ontologią. Witkacemu nie chodziło o ontologie regionalne, lecz o ontologię szerzej rozumianą - w znaczeniu chociażby Ingardena czy w takim znaczeniu, w jakim używał tego terminu ${ }^{32}$. $\mathrm{W}$ pewnym sensie można powiedzieć, że droga Witkacego, a więc droga syntezy ontologii ogólnej z ontologiami regionalnymi, jak najbardziej odpowiada odwiecznym wyobrażeniom o zadaniach filozofii. To, że uwzględniał perspektywę całościową, chroniło go zarówno od ograniczeń platońskiego realizmu, jak i od ograniczeń skrajnego nominalizmu (był umiarkowanym nominalistą), zarówno od sztywnych ram psychologizmu (wywodzącego prawa logiki i matematyki ze struktury przeżyć psychicznych), jak i antypsychologizmu (wywodzącego prawa logiki i matematyki ze struktury obiektywnego bytu).

\section{Bibliografia}

Bedürftig Thomas, Roman Murawski. 2012. Philosophie der Mathematik, Berlin: De Gruyter.

${ }^{32}$ Krzysztof Kościuszko, „Wstęp do metafizyki Stanisława Ignacego Witkiewicza”, Humanistyka i Przyrodoznawstwo 22 (2016), 207-219. 
Bernays Paul. 1967. Hilbert, David. W: Paul Edwards, ed. The Encyclopedia of Philosophy. Vol. 3. 496-504. New York: Macmillan and The Free Press.

Brouwer Luitzen Egbertus Jan. 1998. Mathematics, Science and Language. W: Paolo Mancosu, From Brouwer to Hilbert, New York: Oxford University Press.

Davies Philip J., Reuben Hersh. 1994. Świat matematyki, tłum. Roman Duda. Warszawa: PWN.

Field Hartry. 1989. Realism, Mathematics and Modality. Oxford: Basil Blackwell.

Gödel Kurt. 1995. Is Mathematics Syntax of Language? W: Kurt Gödel, Collected Works, vol. III. Oxford: Oxford University Press.

Hellman Geoffrey. 1990. Modal-Structural Mathematics. W: A.D. Irvine. ed., Physicalism in Mathematics, 307-330. Dordrecht: Kluver.

Kościuszko Krzysztof. 2017. „O Witkiewiczowskim programie ontologizacji matematyki. Cz. 1", Witkacy! 2: 66-68.

Kościuszko Krzysztof. 2017. „O Witkiewiczowskim programie ontologizacji matematyki. Cz. 2", Witkacy! 3: 102-109.

Kościuszko Krzysztof. 2016. „Witkacy uwikłany w spór między absolutną a relacyjną teorią przestrzeni”. Rocznik Podhalański 11: 321-337.

Kościuszko Krzysztof. 2016. „Wstęp do metafizyki Stanisława Ignacego Witkiewicza”. Humanistyka i Przyrodoznawstwo 22: 207-2019.

Quine Willard Van Orman. 1981. Theories and Things. Harvard University Press.

Shapiro Stewart. 1997. Philosophy of Mathematics. Structure and Ontology, Oxford University Press.

Shapiro Stewart. 2000. Thinking about Mathematics. Oxford University Press.

Wang Hao. 1997. Logical Journey: From Gödel to Philosophy. Cambridge: The MIT Press.

Witkiewicz Stanisław Ignacy. 1978. Pisma filozoficzne i estetyczne. Warszawa: PWN.

Witkiewicz Stanisław Ignacy. 1978. Zagadnienie psychofizyczne, oprac. Bohdan Michalski. Warszawa: PWN.

Witkiewicz Stanisław Ignacy. 2011. Pojęcia i twierdzenia implikowane przez pojęcie istnienia. Warszawa: Państwowy Instytut Wydawniczy.

Witkiewicz Stanisław Ignacy. 2014. Nauki ścisłe a filozofia, oprac. Maciej Dombrowski, Magdalena Bizior-Dombrowska. Warszawa: Państwowy Instytut Wydawniczy.

Wójtowicz Krzysztof. 2003. Spór o istnienie w matematyce. Warszawa: Semper. 


\section{Abstract \\ Reflections on Witkiewicz's Philosophy of Mathematics}

In the consequence of the destructive effects of the Second World War on the Witkiewicz's manuscripts his mathematical remarks are very dispersed and incomplete. On the grounds of the rescued fragments of the Witkiewicz's heritage I try to reconstruct the programmatic enunciations of his philosophy of mathematics. I explain the attitude of Witkiewicz - as a conceptualist - towards the platonism. Also in the perspective of the controversy with the platonism I place his views against the background of the mathematical structuralism. I compare Witkiewicz's views with opinions of Wittgenstein, D. Hilbert, G. Hellman and S. Shapiro. I examine the relation between Witkiewicze's and platonistic K. Gödel's philosophy.

Keywords: Brouwer, Carnap, Cornelius H., formalism, Gödel K., Hellman G., Hilbert D., Husserl, intuitionism, logicism, mathematical structuralism, nominalism, ontology of mathematics, Platon, psychologism, platonistic realism, Shapiro S., Witkacy, Wittgenstein

\section{Streszczenie}

\section{Refleksje nad Witkiewiczowską filozofią matematyki}

Konsekwencją destrukcyjnych działań drugiej wojny światowej było rozproszenie i zdekompletowanie matematycznych uwag Witkiewicza zawartych $\mathrm{w}$ jego rękopisach. Na podstawie ocalałych fragmentów Witkiewiczowskiej spuścizny usiłuję zrekonstruować programowe tezy jego filozofii matematyki. Wyjaśniam stosunek Witkiewicza - jako konceptualisty - do platońskiego realizmu. Staram się usytuować jego poglądy na tle matematycznego strukturalizmu. Porównuję poglądy Witkiewicza z poglądami Wittgensteina, D. Hilberta, G. Hellmana i S. Shapiro. Badam relację Witkiewiczowskiej filozofii do filozofii K. Gödla.

Słowa kluczowe: Brouwer, Carnap, Cornelius H., formalism, Gödel K., Hellman G., Hilbert D., Husserl, intuicjonizm, logicyzm, nominalism, ontologia matematyki, Platon, psychologizm, realizm platoński, Shapiro S., strukturalizm matematyczny, Witkacy, Wittgenstein 